\title{
PERANAN KAWASAN KONSERVASI LAUT DALAM MITIGASI PERUBAHAN EKOLOGI LAUT
}

\author{
Oleh \\ Hadiyanto ${ }^{1)}$
}

\begin{abstract}
ROLES OF MARINE PROTECTED AREA IN THE MITIGATION OF MARINE ECOLOGICAL CHANGES. Global warming, overfishing, and coastal pollution are main drivers of marine ecological changes in developing countries, such as Indonesia. Marine Spatial Planning (MSP) prioritizing the establishment of Marine Protected Areas (MPAs) is the local mitigation to reduce the effects of marine ecological changes. It has been acknowledged that MPAs play important roles in: (1) reducing the effects of global warming via uptaking and storing carbon into sediments, (2) protecting marine lifes via providing suitable habitats and maintining natural behaviors, (3) supporting coastal fisheries via exporting adult fishes and larvae, and (4) reducing the effects of coastal pollution via enhancing water and sediment quality. In order to gain maximum benefits, MPAs should meet four standard criteria: (1) representation, i.e. MPAs should cover all marine ecosystems (e.g. mangroves, seagrass beds, and coral reefs), (2) replication, i.e. MPAs should be established in many sites, (3) geographycally widespread network, i.e. among MPAs should be connected, and (4) self-sustaining total area, i.e. MPAs should be large enough to support ecological processes.
\end{abstract}

\section{PENDAHULUAN}

Penyebab utama perubahan ekologi laut di Indonesia adalah pemanasan global, eksploitasi sumberdaya perikanan, dan pencemaran pesisir. Ketiga faktor tersebut menimbulkan dampak yang nyata terhadap ekosistem laut di Indonesia berupa perubahan kekayaan spesies, kelimpahan, distribusi, dan struktur komunitas biota laut (Hadiyanto, 2017). Dampak perubahan ekologi laut terakumulasi di tingkat lokal dan berbeda-beda antara daerah satu dengan lainnya, tergantung pada

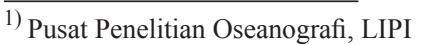

beban eksploitasi sumberdaya perikanan dan pencemaran pesisir (Wenberg et al., 2011).

Perencanaan tata wilayah laut atau Marine Spatial Planning (MSP) merupakan langkah strategis untuk menekan dampak perubahan ekologi laut di Indonesia pada skala nasional dan lokal. MSP merupakan proses politik dalam menganalisa dan mengalokasikan aktivitas manusia baik secara spasial dan temporal agar tujuan-tujuan ekologi, ekonomi, dan sosial masyarakat pesisir tercapai (UNESCO dalam Agardy, 2010). 
Oleh karena itu, MSP dapat menurunkan konflik antarpemangku kepentingan di lingkungan pesisir, sehingga potensi ekologi, ekonomi, dan sosial perairan pesisir dapat dimanfaatkan secara optimal sekaligus menekan penyebab perubahan ekologi laut di pesisir, terutama eksploitasi sumberdaya perikanan dan pencemaran.

Perencana MSP mengintegrasikan semua aktivitas di perairan pesisir dengan cara menyusun zonasi laut secara komprehensif atau Comprehensive Ocean Zoning (COZ). COZ merupakan langkah sederhana, efektif, sistematis, dan strategis untuk mencapai tujuan MSP. COZ melibatkan identifikasi area yang penting secara ekologi, analisa faktorfaktor yang mengancam area tersebut, dan pengembangan skema zonasi yang mencegah aktivitas yang merusak dengan tetap mengizinkan aktivitas yang mendukung kelestarian area tersebut. Oleh karena itu, identifikasi area yang akan dilindungi atau Kawasan Konservasi Laut (KKL) merupakan langkah pertama dalam menyusun COZ agar tujuan MSP tercapai (Agardy, 2010).

Makalah ini membahas secara singkat peran KKL sebagai bagian dari COZ dalam mitigasi perubahan ekologi laut, seperti menekan dampak perubahan iklim, melindungi biota laut, mendukung perikanan pantai, dan menekan dampak pencemaran pesisir. Agar berfungsi secara optimal seperti di atas, KKL harus memenuhi beberapa kriteria standar tertentu. Kriteria tersebut juga dibahas pada makalah ini.

\section{KAWASAN KONSERVASI LAUT MENEKAN DAMPAK PERUBAHAN IKLIM}

Perubahan iklim (pemanasan global dan penurunan $\mathrm{pH}$ air laut) merupakan fenomena global berdampak serius terhadap ekosistem laut. Mitigasi utama perubahan iklim adalah penurunan emisi gas rumah kaca yang dilakukan secara serentak oleh seluruh negara di dunia. Namun demikian, upaya tersebut perlu didukung mitigasi lokal seperti pengembangan Kawasan Konservasi Laut (KKL) untuk perlindungan ekosistem pesisir (mangrove, padang lamun, dan terumbu karang). Ekosistem mangrove dan lamun yang sehat dapat menyerap karbon, dan menyimpannya dalam sedimen (Gambar 1) (Duarte et al., 2013). Perlindungan ekosistem mangrove di Indonesia diestimasi dapat menurunkan emisi karbon yang bersumber dari daratan sebesar $10-31 \%$ (Murdiyarso et al., 2015).

Padang lamun dapat menekan dampak penurunan $\mathrm{pH}$ air laut (ocean acidification) melalui proses fotosintesis. Hal ini dimulai saat padang lamun yang sehat atau dalam kondisi autotrof mampu menyerap karbon anorganik terlarut (Dissolved Inorganic Carbon, DIC) dalam jumlah besar, sehingga menaikkan $\mathrm{pH}$ air laut. Oksigen (sebagai hasil fotosintesis) dilepaskan ke dalam sedimen untuk bereaksi dengan karbonat yang kemudian menghasilkan bikarbonat. Proses ini meningkatkan total alkalinitas sedimen dan menurunkan jumlah DIC sedimen yang akan dilepas kembali ke 
kolom air (Gambar 2). Simulasi proses tersebut menunjukkan bahwa padang lamun mampu meningkatkan $\mathrm{pH}$ air laut 0.38 unit dan omega aragonite 2.9 unit, sehingga laju kalsifikasi karang Scleractinia yang berada di sekitarnya meningkat 18\% (Unsworth et al., 2012).
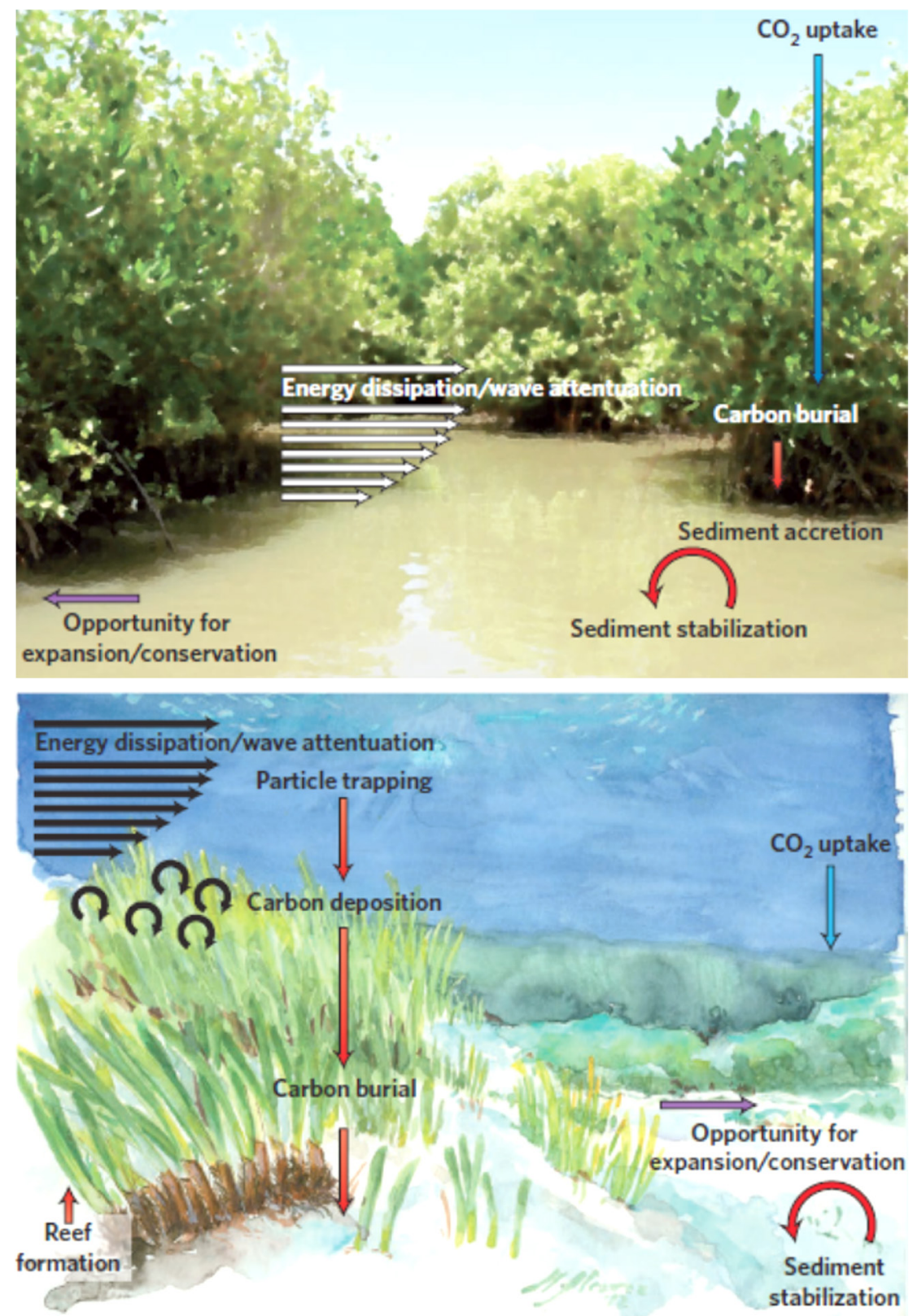

Gambar 1. Peran ekosistem mangrove dan lamun dalam mitigasi perubahan iklim (Duarte et al., 2013). 


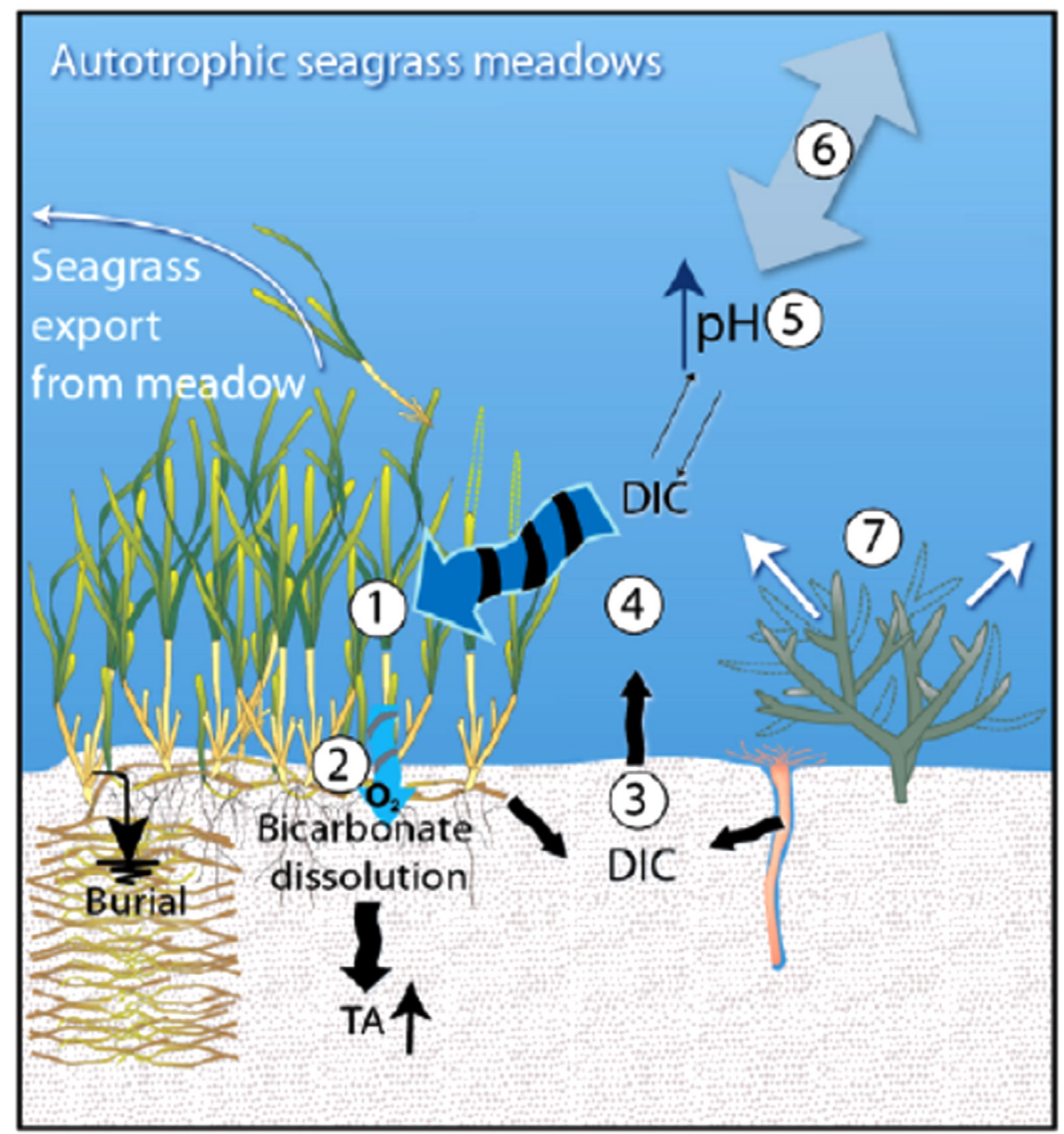

Gambar 2. Peran padang lamun dalam menekan dampak penurunan $\mathrm{pH}$ air laut terhadap terumbu karang (Unsworth et al., 2012).

\section{KAWASAN KONSERVASI LAUT MELINDUNGI BIOTA LAUT}

Laju kepunahan biota laut meningkat, seiring dengan peningkatan degradasi habitat, baik oleh fenomena alam ataupun oleh aktivitas manusia. Kawasan Konservasi Laut (KKL) menyediakan habitat yang cocok untuk biota yang terancam punah, baik biota yang menetap (seperti karang dan kima), maupun biota penjelajah (seperti penyu, tuna, hiu, mamalia laut, dan burung laut), sehingga dapat menahan laju kepunahan biota tersebut (Costello, 2014). 
Ukuran KKL sangat penting bagi biota yang menetap atau biota yang sebarannya relatif sempit, karena seluruh proses kehidupannya berlangsung di lokasi tersebut. KKL berukuran kecil mungkin tidak akan cukup efektif untuk melindungi biota yang tinggal di dalamnya. Sebagai contoh, penelitian di Kepulauan Fiji menunjukkan bahwa predasi karang oleh bintang laut Acanthaster spp. di KKL berukuran kecil 2-3.4 kali lebih tinggi dibandingkan di perairan sekitarnya. KKL berukuran kecil tidak mampu menyediakan predator bintang laut dalam jumlah cukup, sehingga populasinya tidak terkendali dan pada akhirnya memangsa karang dalam jumlah besar (Clements \& Hay, 2017).

Konektivitas antar KKL, serta konektivitas antara KKL dan perairan umum mungkin lebih penting bagi biota penjelajah. Meski biota penjelajah hanya menetap di KKL untuk sementara, keberadaan KKL mampu menurunkan angka mortalitas (Costello, 2014). Konektivitas KKL penting bagi ikanikan yang bermigrasi untuk melanjutkan tahap perkembangannya (ontogenetic migration). Larva ikan untuk sementara tinggal di habitat pengasuhan (nursery ground), kemudian migrasi ke habitat pemijahaan (spawning ground) saat mereka telah matang kelamin (White, 2015). KKL juga berfungsi sebagai tempat persinggahan bagi biota yang bermigrasi dalam jarak yang sangat jauh $(>1000 \mathrm{~km})$ sebelum mencapai lokasi tertentu. Sebagai contoh, Penyu Pipih
(Natator depressus) di Australia Barat bagian utara, telah singgah di $11 \mathrm{KKL}$ sebelum mengakhiri migrasinya sejauh $1150 \mathrm{~km}$ dengan luas area $30,800 \mathrm{~km}^{2}$ (Pendoley et al., 2014).

KKL berperan penting dalam menjaga tingkah laku alami biota laut, seperti aktivitas makan dan reproduksi. Sebagai contoh, ikan kerapu musang (Epinephelus merra) yang tinggal di dalam KKL Kepulauan Fiji memakan biota dengan tingkat trofik lebih tinggi daripada ikan yang tinggal di perairan umum. Hal ini mengindikasikan bahwa ikan di dalam KKL dapat memilih beragam makanan (Dell et al., 2015). Penelitian lain menunjukkan bahwa KKL dapat meningkatkan biomassa ikan yang siap memijah dan menormalisasi rasio kelamin populasi ikan protogini (ikan yang berganti kelamin dari betina menjadi jantan setelah mencapai ukuran tertentu) (Grüss et al., 2014).

\section{KAWASAN KONSERVASI LAUT MENDUKUNG PERIKANAN PANTAI}

Produksi perikanan pantai menurun drastis beberapa dekade ini, karena maraknya ekploitasi sumberdaya perikanan. Kawasan Konservasi Laut (KKL) mampu menjaga stok perikanan di perairan umum, sehingga dapat meningkatkan produksi perikanan pantai. KKL diestimasi dapat meningkatkan tangkapan ikan di perairan umum sebesar 2-4\% per tahun selama kurang lebih 30 tahun (Vandeperre et al., 2011). 
Keberhasilan KKL dalam meningkatkan produksi perikanan telah dilaporkan di beberapa kawasan seperti Afrika, Mediterania, Amerika Utara, Amerika Selatan, Asia, dan Oseania (Costello, 2014).

Peningkatan produksi ikan di perairan umum terjadi karena peran KKL dalam mengekspor ikan dewasa (spillover effect), dan larva (recruitment effect) (Russ et al., 2004). Ekspor ikan dewasa dan larva dari KKL ke perairan umum dapat dijelaskan melalui dua mekanisme, yakni: (1) mekanisme density-dependent, yaitu beberapa ikan akan meninggalkan KKL saat populasi ikan di dalam KKL tinggi sehingga kompetisi terhadap sumberdaya (seperti makanan dan ruang) meningkat, atau (2) mekanisme density-independent, seperti perpindahan karena masih dalam area jelajah, migrasi ontogenetic, dan migrasi karena tingkah laku reproduksi (Di Lorenzo et al., 2016). Pendapat lain menyebutkan bahwa KKL pada awalnya hanya mengekspor ikan dewasa. Jika populasi ikan dewasa di dalam KKL telah maksimum dan stabil, KKL baru mengekspor larva ke perairan umum (Gambar 3) (Kerwath et al., 2013).

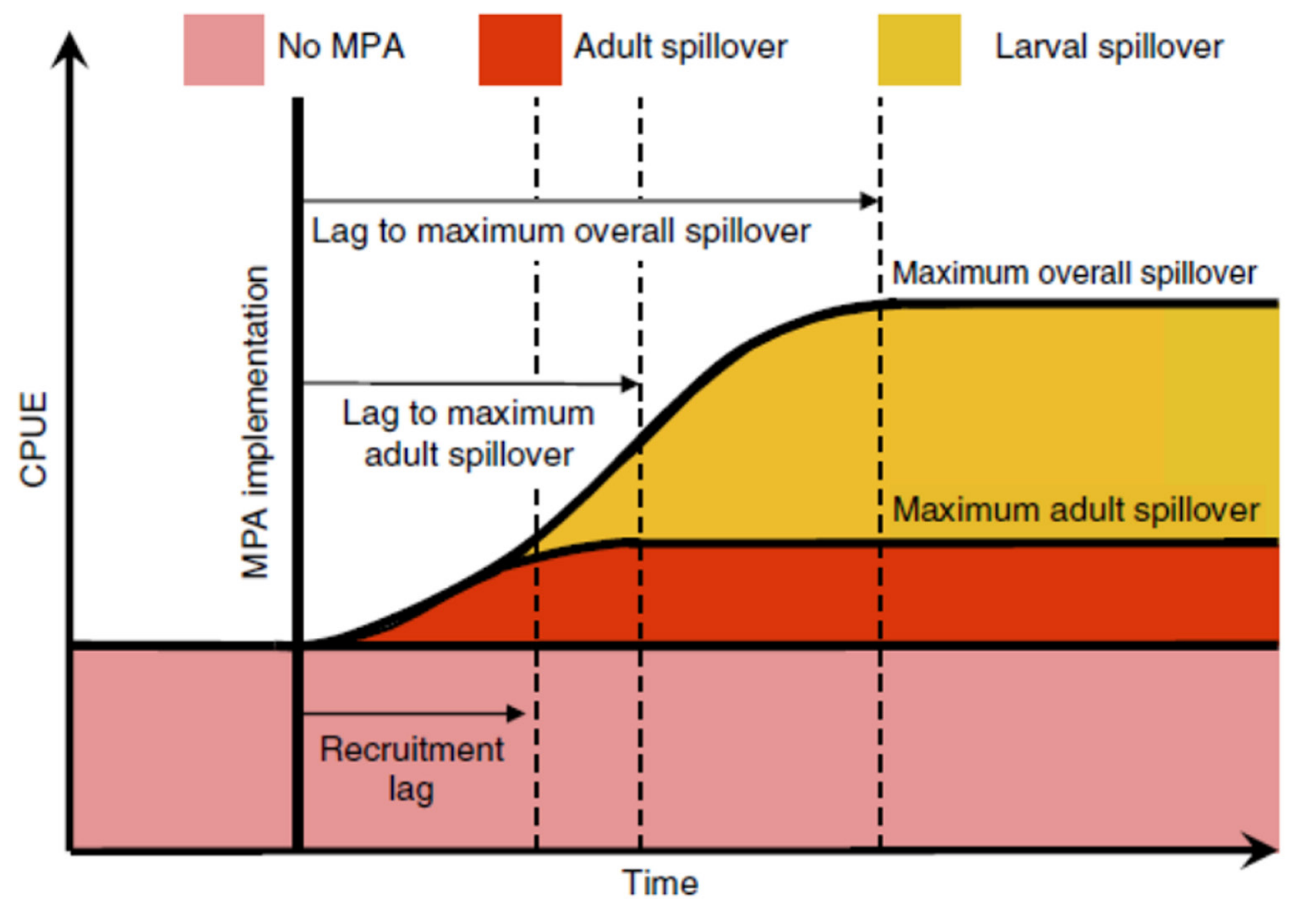

Gambar 3. Mekanisme Kawasan Konservasi Laut dalam meningkatkan produksi perikanan pantai (Kerwath et al., 2013). 
Ekspor ikan dewasa dari KKL ke perairan umum telah dilaporkan di beberapa tempat dengan beragam komoditas perikanan. Hasil penandaan biota di perairan Mediterania menunjukkan bahwa $38 \%$ individu lobster Palinurus elephas yang ditemukan di perairan umum berasal dari KKL di dekatnya (Follesa et al., 2011). Hasil penelitian lain di perairan estuari Laguna Sungai Indian bagian utara, Florida, menunjukkan bahwa 16\% ikan-ikan target untuk rekreasi mancing (seperti Sciaenops ocellatus, Pogonias cromis, Archosargus probatocephalus, Centropomus undecimalis, Cynoscian nebulosus, Carcharhinus leucas, dan Caranx hippos) yang ditemukan di perairan sekitar merupkan hasil limpahan dari KKL di dekatnya (Tremain et al., 2004).

Jumlah ikan yang didapat perairan umum dari ekspor KKL tergantung dari jarak perairan tersebut terhadap batas KKL. Perairan umum yang dekat dengan KKL cenderung menerima limpahan ikan yang lebih banyak. Hasil pemodelan menunjukkan bahwa efek limpahan KKL maksimum sejauh $800 \mathrm{~m}$ dari batas KKL (Halpern et al., 2010). Namun demikian, hasil pengamatan di lapangan dengan metode penandaan biota (tagging) menunjukkan bahwa efek limpahan KKL masih terdeteksi hingga $20 \mathrm{~km}$ dari batas KKL untuk obyek studi lobster (Follesa et al., 2011) dan bahkan hingga $150 \mathrm{~km}$ untuk obyek studi ikan (Tremain et al., 2004).

Ekspor larva dari KKL ke perairan lain dibuktikan melalui studi genetika populasi. Hasil DNA parentage analysis menunjukkan bahwa KKL di Great Barrier Reef mengekspor anakan ikan kerapu merah (Plectropomus maculatus) sebesar $83 \%$ dan anakan ikan kakap (Lutjanus carponotatus) sebesar 55\% ke perairan umum (Harrison et al., 2012). Studi lain menggunakan microsatellite loci analysis menunjukkan bahwa juvenil ikan White Sea Bream (Diplodus sargus sargus) di area KKL dan perairan umum Mediterania memiliki jarak genetik (Fst) yang berbeda tidak nyata ( $>0.05)$. Hasil itu menunjukkan bahwa juvenil ikan di perairan tersebut berasal dari satu populasi, sehingga ada kemungkinan terjadi ekspor-impor antara KKL dan perairan umum (Di Franco et al., 2012).

\section{KAWASAN KONSERVASI LAUT MENEKAN DAMPAK PENCEMARAN PESISIR}

Penurunan kualitas lingkungan pesisir marak terjadi di negara-negara berkembang seperti Indonesia, karena input nutrien dan bahan organik dari aktivitas darat. Ekosistem mangrove dan padang lamun dapat meningkatkan kualitas air dan sedimen laut di lingkungan pesisir. Oleh karena itu, perlindungan kedua ekosistem ini dalam sebuah Kawasan Konservasi Laut (KKL) dapat menekan dampak pencemaran pesisir.

Kemampuan ekosistem mangrove dalam meningkatkan kualitas air di zona pasang-surut (intertidal) telah diketahui beberapa tahun yang lalu. Sebagai contoh, 
hasil penelitian di Distrik Ban Laem, Phetchaburi, Thailand menunjukkan bahwa ekosistem mangrove Avicennia marina (kepadatan $=3,645.83$ pohon $/$ ha, tinggi pohon $=6.17 \mathrm{~m}$, diameter pohon $=$ $6.27 \mathrm{~cm}$, biomassa pohon $=44.03 \mathrm{ton} /$ ha) dapat meningkatkan oksigen terlarut (DO) sebesar $32.39 \%$, dan menurunkan fosfat sebesar $88.23 \%$, amonia sebesar $73.77 \%$, dan nitrat sebesar $64.28 \%$. Potensi alami ini dapat dikombinasikan dengan teknologi buatan manusia untuk pengelolaan limbah terpadu di lingkungan pesisir (Jitthaisong et al., 2012).

Ekosistem mangrove mampu menjebak partikel tersuspensi di kolom air, sehingga dapat menstabilkan sedimen. Hasil penelitian di estuari Vellar, India menunjukkan bahwa konsentrasi partikel tersuspensi di ekosistem mangrove berkisar antara 0.09-0.15 g/l, sedangkan di area tanpa ekosistem mangrove sebesar 0.008-0.01 g/l. Efektivitas ekosistem mangrove dalam menjebak partikel tersuspensi dipengaruhi oleh komposisi jenis pohon penyusunnya. Kombinasi Avicennia-Rhizophora mampu menjebak $30 \%$ partikel tersuspensi yang terbawa pasang-surut, sedangkan jenis Avicennia dan Rhizophora hanya mampu menjebak masing-masing 25\% dan 20\% (Kathiresan, 2003).

Padang lamun mampu meningkatkan kualitas air di lingkungan pesisir, terutama di zona subtidal. Hasil penelitian di Teluk Chesapeake, Florida menunjukkan bahwa padang lamun mampu menurunkan kelebihan nitrat di perairan hingga sepuluh kali lipat. Di lokasi yang sama, konsentrasi oksigen terlarut (DO) di padang lamun 2-8 mg/l lebih tinggi dibandingkan di pesisir tanpa padang lamun. Ini terjadi berkat fotosintesis padang lamun dimana nitrat diserap sebagai sumber nutrien dan oksigen dilepaskan ke kolom air sebagai produk fotosintesis (Moore, 2004).

Padang lamun berpotensi memperbaiki kualitas fisik dan kimia sedimen. Padang lamun tidak hanya mampu menjebak lumpur dan pasir (van Katwijk et al., 2010), tetapi juga menahannya agar tidak berpindah tempat atau tersuspensi kembali ke kolom air (Widdows et al., 2008). Di dalam sedimen, akar lamun melepaskan oksigen (sebagai hasil fotosintesis), sehingga mencegah kondisi anoksik. Hal ini dibuktikan melalui penelitian di Pulau Palawan, Filipina dan Nha Trang, Vietnam yang menunjukkan bahwa potensial redoks di sedimen padang lamun lebih tinggi daripada di sedimen tanpa lamun. Nilai ini juga ditentukan oleh kemampuan fotosintesis lamun. Pemotongan daun lamun Enhalus acaroides sebanyak $1 \mathrm{~m}^{2}$ secara singkat (2 hari) telah menurunkan $50 \%$ anomali redoks positif sedimen (Marbà et al., 2010).

\section{KRITERIA STANDAR KAWASAN KONSERVASI LAUT}

Manfaat Kawasan Konservasi Laut (KKL) dalam mitigasi perubahan ekologi laut dapat diperoleh secara optimal, jika KKL memenuhi kriteria tertentu. KKL yang efektif memiliki empat prinsip, yaitu: representation, replication, geographically widespread network, dan 
self-sustaining total area (Ballantine, 2014).

Representation berarti bahwa KKL harus mencakup seluruh ekosistem laut yang khas pada daerah tersebut, sehingga proses-proses ekologi di dalamnya dapat terjaga (Ballantine, 2014). KKLjuga harus mencakup area dengan keanekaragaman hayati tinggi, area penting untuk fungsi ekosistem atau spesies tertentu, dan area dengan produktivitas tinggi (Stevens, 2002). Ekosistem pesisir tersusun oleh tiga ekosistem utama, yaitu: mangrove, padang lamun, dan terumbu karang. Ketiga ekosistem tersebut terhubung satu sama lain, baik melalui penyebaran biota laut (Honda et al., 2013) atau perpindahan energi (Berkström et al., 2013). Oleh karena itu, KKL di suatu daerah idealnya mencakup ekosistemekosistem tersebut, namun beberapa daerah lain mungkin hanya memiliki satu atau dua tipe ekosistem.

Replication berarti bahwa KKL harus terdapat di beberapa lokasi (Ballantine, 2014). Ini bertujuan untuk mencakup seluruh keanekaragaman habitat di suatu wilayah dan mengantisipasi hilangnya fungsi KKL akibat fenomena alam atau aktivitas manusia (Roberts et al., 2003). Jika salah satu KKL rusak, ada beberapa KKL lain yang masih dapat berfungsi meski mungkin kurang optimal. Oleh karena itu, suatu daerah dengan banyak KKL berukuran lebih kecil lebih efektif dibandingkan dengan daerah dengan hanya satu KKL berukuran lebih besar (Zhou \& Wang, 2006). Jumlah KKL di suatu lokasi tergantung dari variabilitas habitat dan kerentanan habitat-habitat tersebut terhadap faktorfaktor yang mengancam. Beberapa pakar menyarankan bahwa jumlah ideal KKL di suatu wilayah adalah 3-5 buah (Roberts et al., 2003; Fernandes et al., 2005; McLeod et al., 2009).

Geographically widespread network berarti bahwa KKL harus terhubung satu sama lain agar sistem dapat berjalan secara keseluruhan. Konektivitas antar KKL bertujuan untuk memfasilitasi KKL yang sumber biotanya (telur, larva, juvenil, atau dewasa) berasal dari KKL lain (Palumbi, 2003; Ballantine, 2014). Konektivitas antar KKL tergantung dari karakteristik larva (seperti durasi masa larva dan kemampuan berenang larva), kelimpahan sumber populasi, ketersediaan dan kecocokan habitat di sekitarnya, dan karakteristik fisika-kimia lingkungan (seperti kecepatan dan arah arus, suhu, dan salinitas) (Shanks et al., 2003; Treml et al., 2008). Dengan demikian, jarak antara dua KKL yang berdekatan harus cukup untuk memfasilitasi perpindahan biota. Beberapa pakar menyarankan jarak antar KKL idealnya berkisar antara 10$30 \mathrm{~km}$, baik untuk keperluan konservasi maupun perikanan (Shanks et al., 2003; McLeod et al., 2009; Gaines et al., 2010)

Self-sustaining total area berarti bahwa KKL harus cukup luas untuk mendukung proses-proses di dalamnya dan tidak tergantung dari perairan di sekitarnya. Proporsi ukuran KKL dalam suatu perairan tidak dapat dihitung secara tepat, namun terdapat standar umum 
tergantung dari tujuan KKL tersebut, yaitu: $20 \%$ dari luas perairan untuk tujuan konservasi biota laut, dan 30\% dari luas perairan untuk tujuan mendukung perikanan pesisir (Ballantine, 2014). Luas KKL setidaknya $100 \mathrm{~km}^{2}$ agar fungsi perlindungannya optimal (Edgar et al., 2014). Akan tetapi, angka tersebut dapat berubah dengan pertimbangan dua hal, yaitu: jarak dispersal biota yang akan dilindungi (Gambar 4) (Green et al., 2014), dan jumlah individu yang diperlukan untuk kelangsungan populasi (Traill et al., 2007).

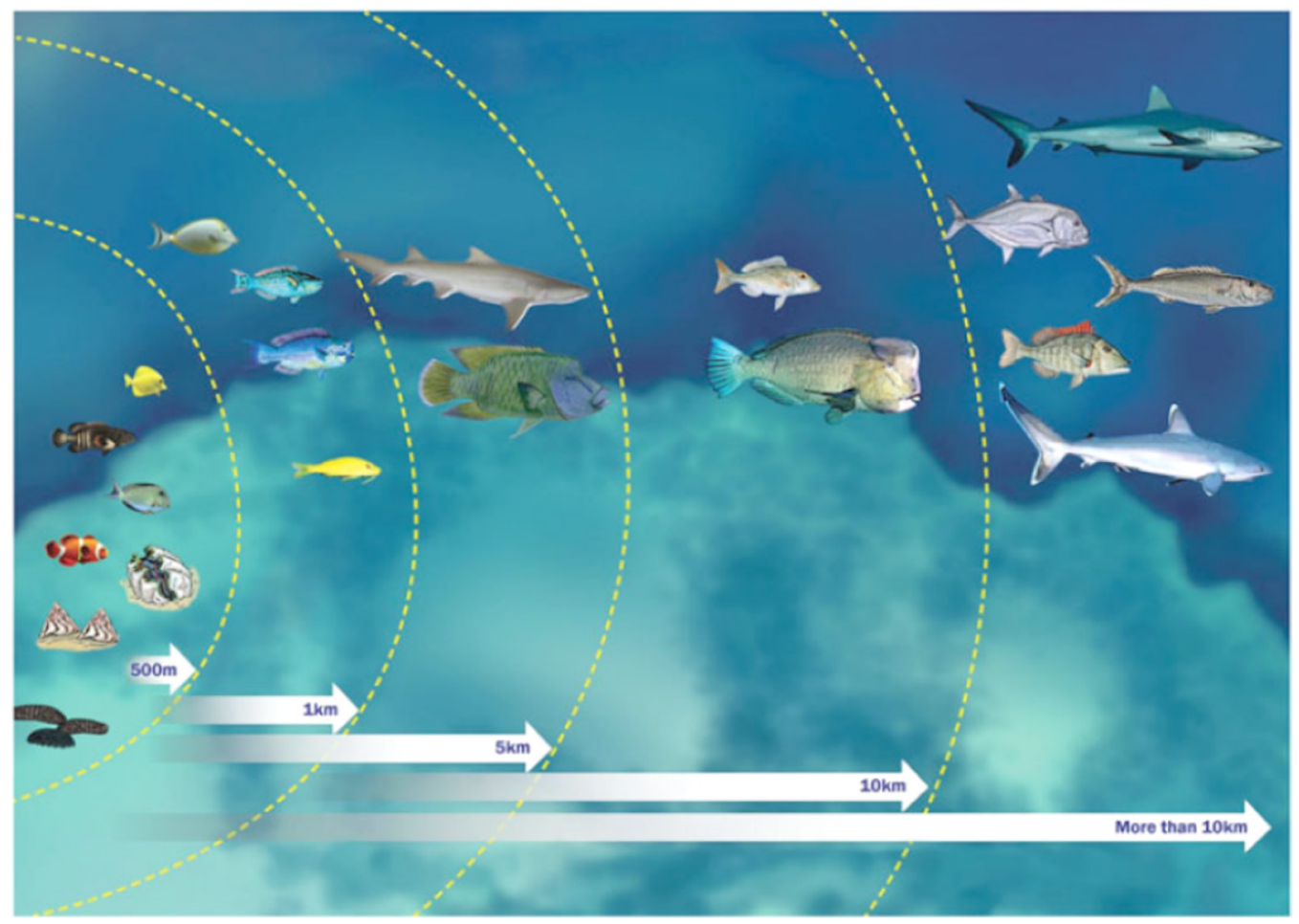

Gambar 4. Area jelajah biota laut untuk pertimbangan luas KKL (Green et al., 2014).

\section{PENUTUP}

Hasil telaah pustaka menunjukkan bahwa Kawasan Konservasi Laut (KKL) mampu menekan dampak perubahan iklim, melindungi biota laut, mendukung perikanan pantai, dan menekan dampak pencemaran pesisir. Oleh karena itu, pengembangan KKL merupakan bentuk mitigasi yang tepat untuk menekan dampak perubahan ekologi laut di
Indonesia, dimana permasalahan seperti pemanasan global, eksploitasi sumber daya perikanan, dan pencemaran pesisir sering terjadi.

KKL yang efektif harus memiliki empat prinsip, yaitu: representation, replication, geographycally widespread network, dan self-sustaining total area, sehingga KKL dapat berfungsi secara optimal. Keempat prinsip tersebut dapat 
digunakan untuk menilai status KKL di Indonesia apakah sudah efektif atau belum dalam menekan dampak perubahan ekologi laut.

\section{DAFTAR PUSTAKA}

Agardy, T. 2010. Ocean zoning: Making marine management more effective. Earthscan, London: $220 \mathrm{pp}$.

Ballantine, B. 2014. Fifty years on: Lessons from marine reserves in new zealand and principles for a worldwide network. Biological Conservation 176: 297-307.

Berkström, C., T. L. Jörgensen and M. Hellström. 2013. Ecological connectivity and niche differentiation between two closely related fish species in the mangrove-seagrasscoral reef continuum. Marine Ecology Progress Series 477: 201-215.

Clements, C. S. and M. E. Hay. 2017. Size matters: Predator outbreaks threaten foundation species in small marine protected areas. PLOS ONE 12: e0171569.

Costello, M. J. 2014. Long live marine reserves: A review of experiences and benefits. Biological Conservation 176: 289-296.

Dell, C., J. P. Montoya and M. E.
Hay. 2015. Effect of Marine Protected Areas (MPAs) on consumer diet: MPA fish feed higher in the food chain. Marine Ecology Progress Series 540: 227-234.

Di Franco, A., G. Coppini, J. M. Pujolar, G. A. De Leo, M. Gatto, V. Lyubartsev, P. Melià, L. Zane and P. Guidetti. 2012. Assessing dispersal patterns of fish propagules from an effective Mediterranean Marine Protected Area. PLOS ONE 7: e52108.

Di Lorenzo, M., J. Claudet and P. Guidetti. 2016. Spillover from Marine Protected Areas to adjacent fisheries has an ecological and a fishery component. Journal for Nature Conservation 32: 62-66.

Duarte, C. M., I. J. Losada, I. E. Hendriks, I. Mazarrasa and N. Marba. 2013. The role of coastal plant communities for climate change mitigation and adaptation. Nature Clim. Change 3: 961968.

Edgar, G. J., R. D. Stuart-Smith, T. J. Willis, S. Kininmonth, S. C. Baker, S. Banks, N. S. Barrett, M. A. Becerro, A. T. F. Bernard, J. Berkhout, C. D. Buxton, S. J. Campbell, A. T. Cooper, M. Davey, S. C. Edgar, G. Forsterra, D. E. Galvan, A. J. Irigoyen, D. J. Kushner, R. Moura, P. E. Parnell, N. 
T. Shears, G. Soler, E. M. A. Strain and R. J. Thomson. 2014. Global conservation outcomes depend on Marine Protected Areas with five key features. Nature 506: 216-220.

Fernandes, L., J. O. N. Day, A. Lewis, S. Slegers, B. Kerrigan, D. A. N. Breen, D. Cameron, B. Jago, J. Hall, D. Lowe, J. Innes, J. Tanzer, V. Chadwick, L. Thompson, K. Gorman, M. Simmons, B. Barnett, K. Sampson, G. De'Ath, B. Mapstone, H. Marsh, H. Possingham, I. A. N. Ball, T. Ward, K. Dobbs, J. Aumend, D. E. B. Slater and K. Stapleton. 2005. Establishing representative no-take areas in the Great Barrier Reef: Largescale implementation of theory on marine protected areas. Conservation Biology 19: 1733-1744.

Follesa, M. C., R. Cannas, A. Cau, D. Cuccu, A. Gastoni, A. Ortu, C. Pedoni, C. Porcu and A. Cau. 2011. Spillover effects of a Mediterranean Marine Protected Area on the European SpinyLobster Palinurus elephas (Fabricius, 1787) resource. Aquatic Conservation: Marine and Freshwater Ecosystems 21: 564-572.

Gaines, S. D., C. White, M. H. Carr and S. R. Palumbi. 2010. Designing marine reserve networks for both conservation and fisheries management. Proceedings of the National Academy of Sciences of the United States of America 107: 18286-18293.

Green, A. L., L. Fernandes, G. Almany, R. Abesamis, E. McLeod, P. M. Aliño, A. T. White, R. Salm, J. Tanzer and R. L. Pressey. 2014. Designing marine reserves for fisheries management, biodiversity conservation, and climate change adaptation. Coastal Management 42: 143159.

Grüss, A., J. Robinson, S. S. Heppell, S. A. Heppell and B. X. Semmens. 2014. Conservation and fisheries effects of spawning aggregation marine protected areas: What we know, where we should go, and what we need to get there. ICES Journal of Marine Science 71: 15151534.

Hadiyanto, 2017. Pemanasan global, eksploitasi sumberdaya perikanan, dan pencemaran pesisir sebagai penyebab utama perubahan ekologi laut di Indonesia. Oseana XLII: 1-11.

Halpern, B. S., S. E. Lester and J. B. Kellner. 2010. Spillover from marine reserves and the replenishment of fished stocks. Environmental Conservation 36: 268-276.

Harrison, H. B., D. H. Williamson, R. 
D. Evans, G. R. Almany, S. R. Thorrold, G. R. Russ, K. A. Feldheim, L. van Herwerden, S. Planes, M. Srinivasan, M. L. Berumen and G. P. Jones. 2012. Larval export from marine reserves and the recruitment benefit for fish and fisheries. Current Biology 22: 10231028.

Honda, K., Y. Nakamura, M. Nakaoka, W. H. Uy and M. D. Fortes. 2013. Habitat use by fishes in coral reefs, seagrass beds and mangrove habitats in the Philippines. PLoS ONE 8: e65735.

Jitthaisong, O., K. Chunkao, P. Dhanmanonda and S. Teejuntuk. 2012. Water quality from mangrove forest: The King's Royally initiated Laem Phak Bia environmental research and development project, Phetchaburi Province, Thailand. Modern Applied Science 6: 1-8.

Kathiresan, K. 2003. How do mangrove forests induce sedimentation? Revista de Biología Tropical 51: 355-360.

Kerwath, S. E., H. Winker, A. Götz and C. G. Attwood. 2013. Marine Protected Area improves yield without disadvantaging fishers. Nature Communications 4: 2347.
Marbà, N., C. M. Duarte, J. Terrados, Z. Halun, E. Gacia and M. D. Fortes. 2010. Effects of seagrass rhizospheres on sediment redox conditions in SE Asian coastal ecosystems. Estuaries and Coasts 33: 107-117.

McLeod, E., R. Salm, A. Green and J. Almany. 2009. Designing Marine Protected Area networks to address the impacts of climate change. Frontiers in Ecology and the Environment 7: 362-370.

Moore, K. 2004. Influence of seagrasses on water quality in shallow regions of the lower Chesapeake Bay. Journal of Coastal Research: 162-178.

Murdiyarso, D., J. Purbopuspito, J. B. Kauffman, M. W. Warren, S. D. Sasmito, D. C. Donato, S. Manuri, H. Krisnawati, S. Taberima and S. Kurnianto. 2015. The potential of Indonesian mangrove forests for global climate change mitigation. Nature Clim. Change 5: 1089-1092.

Palumbi, S. R. 2003. Population genetics, demographic connectivity, and the design of marine reserves. Ecological Applications 13: S146-S158.

Pendoley, K. L., G. Schofield, P. A. Whittock, D. Ierodiaconou and G. C. Hays. 2014. Protected 
species use of a coastal marine migratory corridor connecting marine protected areas. Marine Biology 161: 1455-1466.

Roberts, C. M., G. Branch, R. H. Bustamante, J. C. Castilla, J. Dugan, B. S. Halpern, K. D. Lafferty, H. Leslie, J. Lubchenco, D. McArdle, M. Ruckelshaus and R. R. Warner. 2003. Application of ecological criteria in selecting marine reserves and developing reserve networks. Ecological Applications 13: S215-S228.

Russ, G. R., A. C. Alcala, A. P. Maypa, H. P. Calumpong and A. T. White. 2004. Marine reserve benefits local fisheries. Ecological Applications 14: 597-606.

Shanks, A. L., B. A. Grantham and M. H. Carr. 2003. Propagule dispersal distance and the size and spacing of marine reserves. Ecological Applications 13: S159-S169.

Stevens, T. 2002. Rigor and representativeness in Marine Protected Area design. Coastal Management 30: 237-248.

Traill, L. W., C. J. A. Bradshaw and B.W. Brook. 2007. Minimum viable population size: A meta-analysis of 30 years of published estimates. Biological Conservation 139: 159-166.

Tremain, D. M., C. W. Harnden and D. H.
Adams. 2004. Multidirectional movements of sportfish species between an estuarine no-take zone and surrounding waters of the Indian River Lagoon, Florida. Fishery Bulletin 102(3): 533-544.

Treml, E. A., P. N. Halpin, D. L. Urban and L. F. Pratson. 2008. Modeling population connectivity by ocean currents, a graphtheoretic approach for marine conservation. Landscape Ecology 23: 19-36.

Unsworth, R. K. F., C. J. Collier, G. M. Henderson and L. J. McKenzie. 2012. Tropical seagrass meadows modify seawater carbon chemistry: Implications for coral reefs impacted by ocean acidification. Environmental Research Letters 7: 024026.

van Katwijk, M. M., A. R. Bos, D. C. R. Hermus and W. Suykerbuyk. 2010. Sediment modification by seagrass beds: Muddification and sandification induced by plant cover and environmental conditions. Estuarine, Coastal and Shelf Science 89: 175-181.

Vandeperre, F., R. M. Higgins, J. Sánchez-Meca, F. Maynou, R. Goñi, P. Martín-Sosa, A. PérezRuzafa, P. Afonso, I. Bertocci, R. Crec'hriou, G. D'Anna, M. Dimech, C. Dorta, O. Esparza, J. M. Falcón, A. Forcada, I. Guala, L. Le Direach, C. 
Marcos, C. Ojeda-Martínez, C. Pipitone, P. J. Schembri, V. Stelzenmüller, B. Stobart and R. S. Santos. 2011. Effects of no-take area size and age of Marine Protected Areas on fisheries yields: A metaanalytical approach. Fish and Fisheries 12: 412-426.

Wernberg, T., B. D. Russell, P. J. Moore, S. D. Ling, D. A. Smale, A. Campbell, M. A. Coleman, P. D. Steinberg, G. A. Kendrick and S. D. Connell. 2011. Impacts of climate change in a global hotspot for temperate marine biodiversity and ocean warming. Journal of Experimental Marine Biology and Ecology 400: 7-16.
White, J. W. 2015. Marine reserve design theory for species with ontogenetic migration. Biology Letters 11: 20140511.

Widdows, J., N. D. Pope, M. D. Brinsley, H. Asmus and R. M. Asmus. 2008. Effects of seagrass beds (Zostera noltii and Z. marina) on near-bed hydrodynamics and sediment resuspension. Marine Ecology Progress Series 358: 125-136.

Zhou, S. R. and G. Wang. 2006. One large, several medium, or many small? Ecological Modelling 191: 513-520. 